\title{
Social Sustainability in Workplace: An Investigation of the Buyer-Supplier Relationship through Power and Psychologically Defensive Workplace Behavior
}

\author{
Md. Rafiqul Islam Rana and Jung E. Ha-Brookshire, University of Missouri, USA
}

Keywords: social sustainability, buyer-supplier, workplace behavior

The US Environmental Protection Agency (EPA) (2017) stated that to increase growth and global competitiveness, many companies are considering "sustainability" as a crucial objective in their strategy. However, when most of the companies are focusing on improving "Machine" and "Material", "Man" factor is often very little discussed. This study aimed to investigate the relationship between the power of buyers (usually from developed countries) and subsequent workplace behavior of suppliers (usually from developing countries) in the global textile and apparel (T\&A) supply chain. Workplace behavior of managers in supplier firms could have a direct impact on the overall well-being of factory workers as they have direct and daily interactions with workers.

The two power bases, reward and coercive, were investigated from the social power theory perspective (French \& Raven, 1959). Reward power (RP) is defined as the ability to administer positive valence or decrease negative valence, which is often used by buyers to induce desired behaviors from suppliers. Buyers also use coercive power (CP) which is defined as the ability to punish if the power recipient fails to respond and to pressure suppliers to comply with the buyers' requirements. Allcorn and Diamond (1997) said, when an organization does not promote security, autonomy, and self-esteem, the employees in that organization tends to defend themselves psychologically, and they coined the term psychologically defensive workplace behavior (PDWB). The authors proposed three major types of PDWB: (a) perfectionist behavior (PF) [authoritarian and hyper-critical]; (b) arrogant-vindictive behavior (AV) [unethical and manipulative]; and (c) narcissistic behavior (NP) [non-cooperative and whimsical].

An online survey was used to collect the data from the T\&A companies in Bangladesh (given it is the 2nd largest exporter of textiles and apparel to the world) (Mridha, 2016) using snowballing and convenient sampling techniques. The measurement items for suppliers' (in this study, factory managers') perceived reward and coercive power from buyers were adapted from Zhao et al. (2008). The measurement items for the suppliers' PDWB have been adopted from Allcorn and Diamond (1997). A total of 205 usable responses were collected in spring 2018.

Page 1 of 2

Published under a Creative Commons Attribution License (https://creativecommons.org/licenses/by/4.0/), which permits unrestricted use, distribution, and reproduction in any medium, provided the original work is properly cited. 
The results of the multiple regression analyses showed that the perceived buyers' $R P$ ( $\beta 1=.202$, $\mathrm{p}<.01), \mathrm{CP}(\beta 2=.219, \mathrm{p}<.01)$ were associated with the respondents' PF. The perceived buyers' $\mathrm{RP}(\beta 1=.158, \mathrm{p}<0.05)$ and $\mathrm{CP}(\beta 2=.378, \mathrm{p}<.001)$ were associated with the respondents' AV. Finally, the perceived buyers' RP $(\beta 1=.209, \mathrm{p}<.01)$ was associated with the respondents' NP. However, the perceived $\mathrm{CP}(\beta 2=.062, \mathrm{p}>.05)$ from the buyer was not associated with the respondents' NP.

The findings of this study help illustrate the human behavioral aspects within the sustainable workplace development context. That is, the findings shed lights into corporate social responsibility issues beyond the usual measurement of the codes of conduct and compliance issues. When managers show psychologically defensive behaviors, workers' well-being might be jeopardized, and such disruptive behaviors could be aroused by buyers' power exercise. The study proposes future research opportunities for additional dimensions of corporate social responsibility beyond compliance issues.

\section{References}

Allcorn, S., \& Diamond, M.A. (1997). Managing people during stressful times: The psychologically defensive workplace. Westport, CT: Quorum Books.

French, J. R., \& Raven, B. (1959). The bases of social power. In C. Dorwin (Ed.), Studies in social power. Ann Arbor: University of Michigan Press.

Mirdha, R. U. (2016, July 17). Bangladesh remains second largest garments exporter, against all odds. Retrieved from http://www.thedailystar.net/country/bangladesh-remains-secondlargest-garments-exporter-against-all-odds-1255084

United States Environmental Protection Agency (2017), Learn About Sustainability. Retrieved from https://www.epa.gov/sustainability/learn-about-sustainability\#what

Zhao, X., Huo, B., Flynn, B., \& Yeung, J. (2008). The impact of power and relationship commitment on the integration between manufacturers and customers in a supply chain. Journal of Operations Management, 26, 368-388. 